\title{
Association between CYP1A1 gene polymorphisms and cervical cancer susceptibility: a meta-analysis
}

\author{
Mingxia Shen ${ }^{1}$, Juan Wang ${ }^{2}$, Junqi Ma²
}

${ }^{1}$ Affiliated Tumor Hospital, Xinjiang Medical University, Ürümqi, China

${ }^{2}$ The First Affiliated Hospital of Xinjiang Medical University, Ürümqi, China

Submitted: 9 May 2019; Accepted: 25 December 2019

Online publication: 25 March 2021

Arch Med Sci

DOI: https://doi.org/10.5114/aoms/115846

Copyright $\odot 2021$ Termedia \& Banach

\section{Abstract}

Introduction: The aim of this study is to systemically analyze the association of CYP1A1 gene Mspl and Ile462Val polymorphisms with cervical cancer susceptibility.

Material and methods: The publications about the associations between CYP1A1 polymorphism and cervical cancer were retrieved through PubMed, Embase, Chinese Biomedical Literature Database, Wanfang Data, Database of Chinese Scientific and Technical Periodicals (VIP) and China Knowledge Network. The Hardy-Weinberg equilibrium test was used to evaluate the quality of the included studies, and the data in the studies selected were analyzed by Stata 12.0 software. Potential publication bias was assessed with funnel plots and a modified Egger's linear regression test.

Results: A total of 17 studies were enrolled in this analysis. There were 14 articles on the Mspl polymorphism, including 2448 cases and 2520 controls. We found a significant association between $\mathrm{Mspl}$ polymorphism and cervical cancer susceptibility ( $C$ vs. T, $O R=1.333,95 \% \mathrm{Cl}: 1.214-1.464$, $p \leq 0.001$; CC vs. TT, OR $=1.962,95 \%$ Cl: $1.571-2.450, p \leq 0.001 ; \mathrm{CC} / \mathrm{CT}$ vs.TT, $\mathrm{OR}=1.591,95 \% \mathrm{Cl}: 1.406-1.800, p \leq 0.001 ; \mathrm{CC}$ vs.TT/CT, OR $=1.429,95 \% \mathrm{Cl}:$ $1.177-1.736, p \leq 0.001$ ). In total, 11 articles, including 2137 cases and 2116 controls, analyzed the lle $462 \mathrm{Val}$ polymorphism and the risk of cervical cancer. The results showed a significant association between Ile462Val polymorphism and cervical cancer susceptibility (Val vs. Ile, OR $=1.338,95 \% \mathrm{Cl}$ : 1.199-1.493, $p \leq 0.001$; ValVal vs. Ilelle, $\mathrm{OR}=1.576,95 \% \mathrm{Cl}: 1.188-2.090$, $p=0.002$; ValVal/Vallle vs. Helle, $\mathrm{OR}=1.498 ; 95 \% \mathrm{Cl}: 1.299-1.728, p \leq 0.001$ ). Conclusions: Both Mspl and Ile462Val polymorphisms of the CYP1A1 gene are associated with the risk of cervical cancer.

Key words: cervical cancer, CYP1A1, Mspl polymorphism, Ile462Val polymorphism, meta-analysis.

\section{Introduction}

Cervical cancer is one of the most common gynecological malignancies. High-risk HPV infection is a risk factor for cervical cancer [1, 2]. In a cost-effectiveness study of different cervical screening approaches in developing countries, screening females once in a lifetime, at the age of 35 years, with a one- or two-visit screening strategy involving VIA or HPV testing reduced lifetime risk of cancer by approximately $25-36 \%$ [3]. However, less than $1 \%$ of HPV-infected patients suffer from cervical cancer, suggesting that early sexual activity, multiple partners, and frequent change of partners are also related to cervical cancer and that high-risk 
HPV infection is a necessary but insufficient factor for cervical cancer [4-6]. Despite evidence showing the protective effect of HPV vaccine against cervical cancer, it is still a dilemma whether to introduce this vaccine as a routine in several other countries such as India, Sweden and Japan [7]. Smoking, drinking, long-term usage of oral contraceptives and other risk factors may also lead to the occurrence of cervical cancer [8, 9]. The identification of risk factors is critical for the treatment of cervical cancer and in-depth understanding of the disease.

The cytochrome P450 1A1 (CYP1A1) gene is a key member of the CYP1 family and is involved in the metabolism of endogenous and exogenous compounds in vivo. For example, benzopyrene becomes an active and carcinogenic intermediate following CYP1A1 metabolism [10]. In addition, phenylphosphatol estrogen is formed after catalysis by CYP1A1, which further leads to the formation of ROS and DNA adducts and the occurrence of mutations during DNA replication [11-14]. Studies have shown that genomic instability caused by gene mutation and chromosome rearrangement is one of the most important factors for tumorigenesis [15-17]. It is reported that two polymorphisms of CYP1A1, Mspl (T3801C, rs4646903) and lle462Val (A4889G, rs1048943), are closely related with cervical cancer [18-22]. The Rs4646903 polymorphism is located in the 3' untranslated region, while the rs 1048943 polymorphism is located on exon 7 , whose mutation results in the substitution of an amino acid at position $462[23,24]$. Point mutations at rs4646903 and rs1048943 can lead to dysregulated CYP1A1 mRNA expression [17]. A number of studies have reported the association between the two polymorphisms and the occurrence of cervical cancer in different ethnic groups, but the conclusions of different studies are still inconsistent $[20,21]$.

In this study, meta-analysis was used to evaluate the association of CYP1A1 rs4646903 and rs 1048943 polymorphisms with cervical cancer. Our data may provide a basis for further study on the role of genetic factors in the pathogenesis of cervical cancer.

\section{Material and methods}

\section{Literature retrieval}

Literature reporting the association of CYP1A1 polymorphism and cervical cancer was retrieved through PubMed, Embase, Chinese Biomedical Literature Database, Wanfang Data, Database of Chinese Scientific and Technical Periodicals (VIP) and China Knowledge Network. The keywords for retrieval were 'cytochrome P4501A1' or 'CYP1A1' or 'Ile462Val' or 'A4889G' or 'rs1048943' or 'Mspl' or
'T3801C' or 'rs4646903' and 'cervical carcinoma' or 'cervical cancer' or 'cervix cancer'. At the same time, the reference list of the retrieved literature was manually entered into the above mentioned databases to screen more suitable literature.

\section{Eligibility criteria}

Studies were included in the meta-analysis i they met the following criteria: 1) they appeared online or in a peer-reviewed journal published in English or Chinese before 31 March 2017; 2) they were case-control studies; 3 ) the control group comprised healthy individuals; 4) the full text could be retrieved; 5) the distribution frequency of the CYP1A1 gene polymorphisms or the corresponding OR value is provided and the data are clearly expressed.

The exclusion criteria were as follows: 1) articles with incomplete data; 2) articles with cervical intraepithelial neoplasia or non-cervical cancer patients as research subjects; 3 ) the studies only researched the correlation between progression, severity, phenotypic modification, sensitivity to response to treatment, or survival with gene polymorphism; 4) articles with family relevance analysis; 5) repetitive reports or articles with poor quality or limited information.

The outcome indicator of this study is the incidence of cervical carcinoma.

\section{Data extraction}

Data were extracted by two authors independently. Disagreements were resolved by discussion or a third person. The following data were extracted from each study: year of publication, first author, the country where the study was performed, the ethnicity of participants, genotyping methods, genes and genotype data. We classified case selection as population-based if the study included data from different ethnicities, including Caucasians, Asians and others. The Hardy-Weinberg equilibrium (HWE) test was used to evaluate the quality of the enrolled studies.

\section{Statistical analysis}

Statistical analysis was performed with STATA version 12.0 (Stata Corporation, College Station, TX, USA). The Hardy-Weinberg equilibrium (HWE) in the controls was tested by the chi-square test for goodness of fit. For the genetic variants, allelic, homozygous, dominant and recessive models were computed. Estimates of association between CYP1A1 polymorphism and cervical cancer were evaluated by odds ratios (ORs) and corresponding $95 \%$ confidence intervals (Cls). Heterogeneity between studies was assessed by the Cochran Q statistic and $r^{2}$ statistic. Generally, $p>0.1$ and 
$1^{2}<25 \%$ correspond to heterogeneity; and $p<0.1$ and $l^{2}>50 \%$ correspond to large heterogeneity. If the data were heterogeneous, a random effects model was adopted; if the data were homogeneous, a fixed effects model was applied. Potential publication bias was assessed with funnel plots and a modified Egger's linear regression test was used to identify significant asymmetry. For all data, two-tailed tests were used throughout and $P<0.05$ was considered significant.

\section{Results}

\section{Basic information of included studies}

A total of 130 articles were identified according to the keywords (Figure 1). After being screened by title and abstract, 109 articles including 47 irrelevant articles, 41 articles with overlapping data, 4 reviews and 17 articles on animals or cells were excluded. The remaining publications underwent screening of the full text, identifying a total of 17 eligible articles that included 14 articles on the Mspl polymorphism [19-22, 25-34] and 11 on the lle462Val polymorphism [20, 25-28, 31-33, 35-37] of the CYP1A1 gene. All articles included in the meta-analysis are shown in Table I.

\section{Meta-analysis results for Mspl}

For the 14 articles on the Mspl polymorphism, 2248 patients and 2520 healthy controls were en-

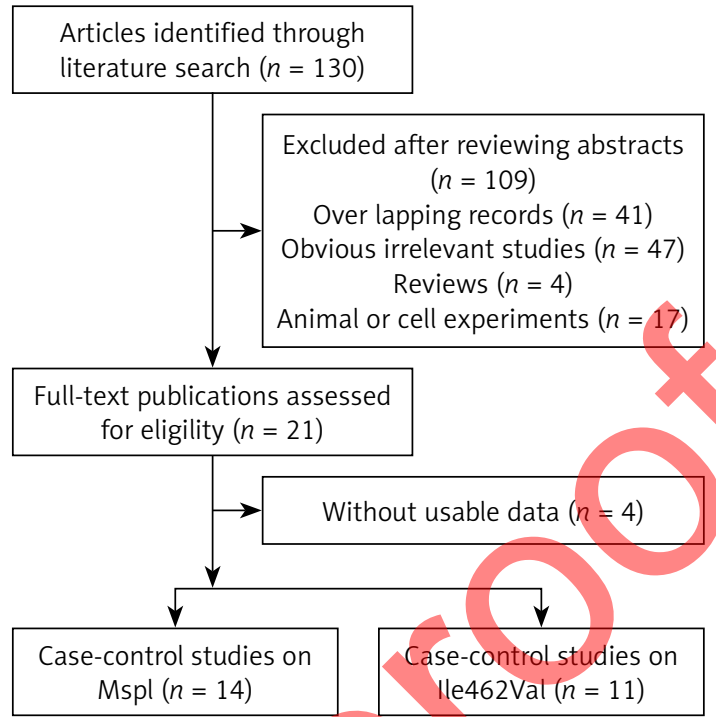

Figure 1. Study flow chart explaining the selection of the seventeen eligible case control articles enrolled in the meta-analysis

rolled. As shown in Figure 2, we found that the Mspl polymorphism of the CYP1A1 gene was significantly associated with susceptibility to cervical cancer (Figure $2 \mathrm{~A}, \mathrm{C}$ vs. T, OR $=1.333,95 \% \mathrm{Cl}$ : $1.214-1.464, p \leq 0.001$ ) (Figure $2 \mathrm{~B}, \mathrm{CC}$ vs. TT, $\mathrm{OR}=1.962,95 \% \mathrm{Cl}: 1.571-2.450, p \leq 0.001$ ) (Figure 2 C, CC/CT vs.TT, OR $=1.591,95 \% \mathrm{Cl}: 1.406-$ $1.800, p \leq 0.001$ ) (Figure $2 \mathrm{D}, \mathrm{CC}$ vs. TT/CT, OR = $1.429,95 \% \mathrm{Cl}: 1.177-1.736, p \leq 0.001)$.

Table I. Quality scores of studies included in the meta-analysis

\begin{tabular}{|c|c|c|c|c|c|}
\hline Author (year) & Ethnicity & $\begin{array}{l}\text { Study } \\
\text { design }\end{array}$ & $\begin{array}{l}\text { Polymorphisms } \\
\text { studied }\end{array}$ & $\begin{array}{l}\text { Genotyping } \\
\text { method }\end{array}$ & $\begin{array}{c}\text { HWE } \\
\text { in controls }\end{array}$ \\
\hline Kim (2000) & Asians & $\mathrm{HCS}$ & Mspl & PCR-RFLP & 0.05 \\
\hline Sugawara (2003) & Asians & HCS & Mspl, Ile462Val & PCR-RFLP & $0.23 / 0.28$ \\
\hline Taskiran (2006) & Caucasian & $\mathrm{HCS}$ & Ile462Val & PCR-RFLP & 0.15 \\
\hline Joseph (2006) & Caucasian & HCS & Mspl, Ile462Val & PCR-RFLP & $0.24 / 0.20$ \\
\hline Juarez-Cedillo (2007) & others & $\mathrm{HCS}$ & Mspl & PCR-RFLP & 0.64 \\
\hline Li (2009) & Asians & $\mathrm{HCS}$ & Mspl, Ile462Val & PCR-RFLP & $0.56 / 0.36$ \\
\hline Gutman (2009) & Caucasian & HCS & Mspl, Ile462Val & PCR-RFLP & $0.39 / 0.30$ \\
\hline Geng (2010) & Asians & $\mathrm{HCS}$ & Ile462Val & PCR-RFLP & 0.01 \\
\hline Shi (2011) & Asians & $\mathrm{HCS}$ & Mspl, Ile462Val & PCR-RFLP & $0.87 / 0.25$ \\
\hline Ding (2011) & Asians & $\mathrm{HCS}$ & Mspl, Ile462Val & PCR-RFLP & $0.04 / 0.003$ \\
\hline Von (2011) & Caucasian & & Mspl & PCR-RFLP & 0.18 \\
\hline Abbas (2014) & Caucasian & $\mathrm{HCS}$ & Mspl, Ile462Val & PCR-RFLP & $0.36 / 0.30$ \\
\hline Roszak (2014) & Caucasian & $\mathrm{HCS}$ & Ile462Val & PCR-RFLP & 1.00 \\
\hline Kleine (2015) & Caucasian & $\mathrm{HCS}$ & Mspl & PCR-RFLP & 0.23 \\
\hline $\operatorname{Tan}(2016)$ & Mixed & $\mathrm{HCS}$ & Mspl & PCR-RFLP & 0.94 \\
\hline Matos (2016) & Caucasian & HCS & Mspl & PCR-RFLP & 0.81 \\
\hline Li (2016) & Asians & HCS & Mspl, Ile462Val & Taqman & $0.79 / 0.84$ \\
\hline
\end{tabular}

HWE - Hardy-Weinberg equilibrium. 
A

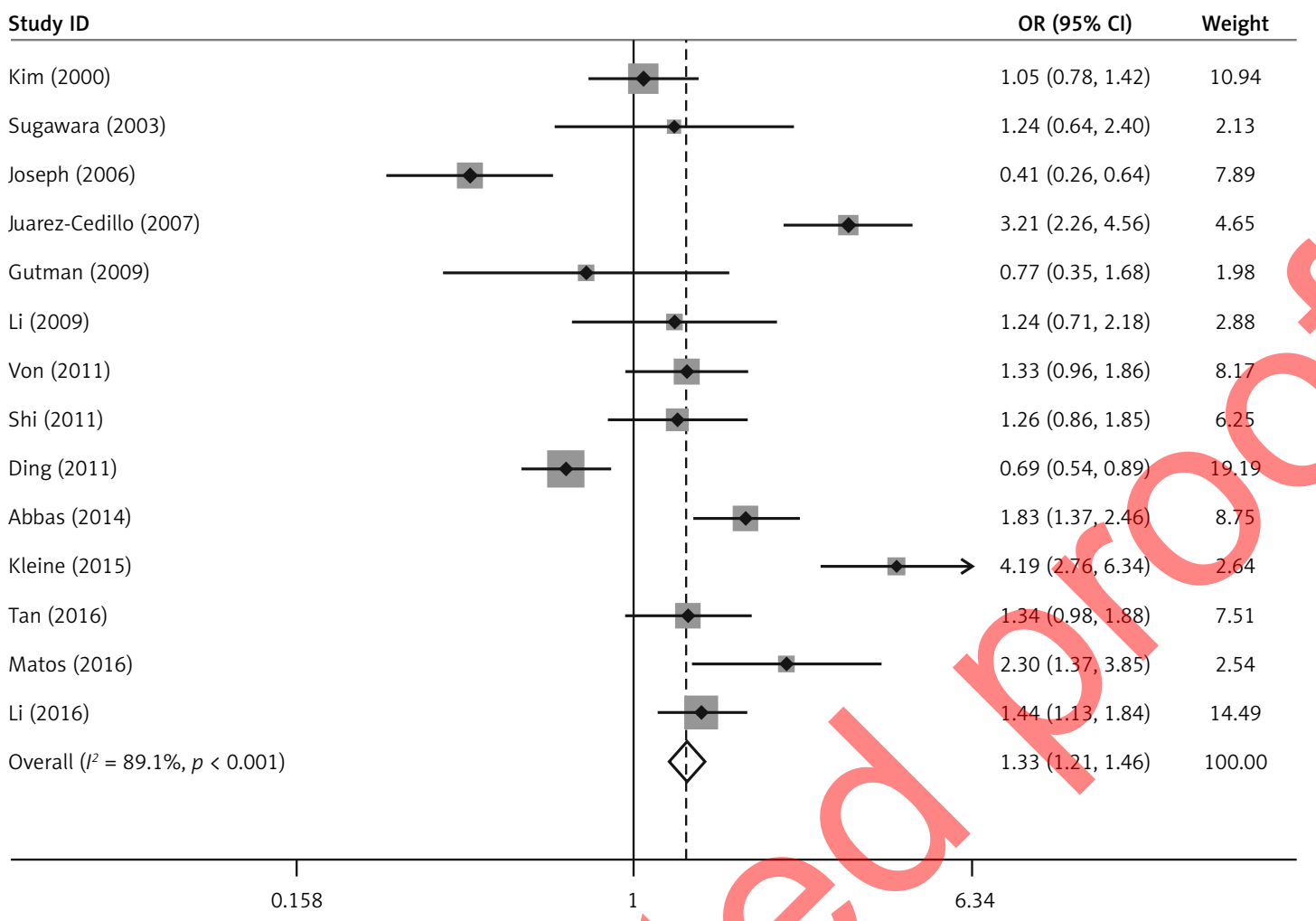

B

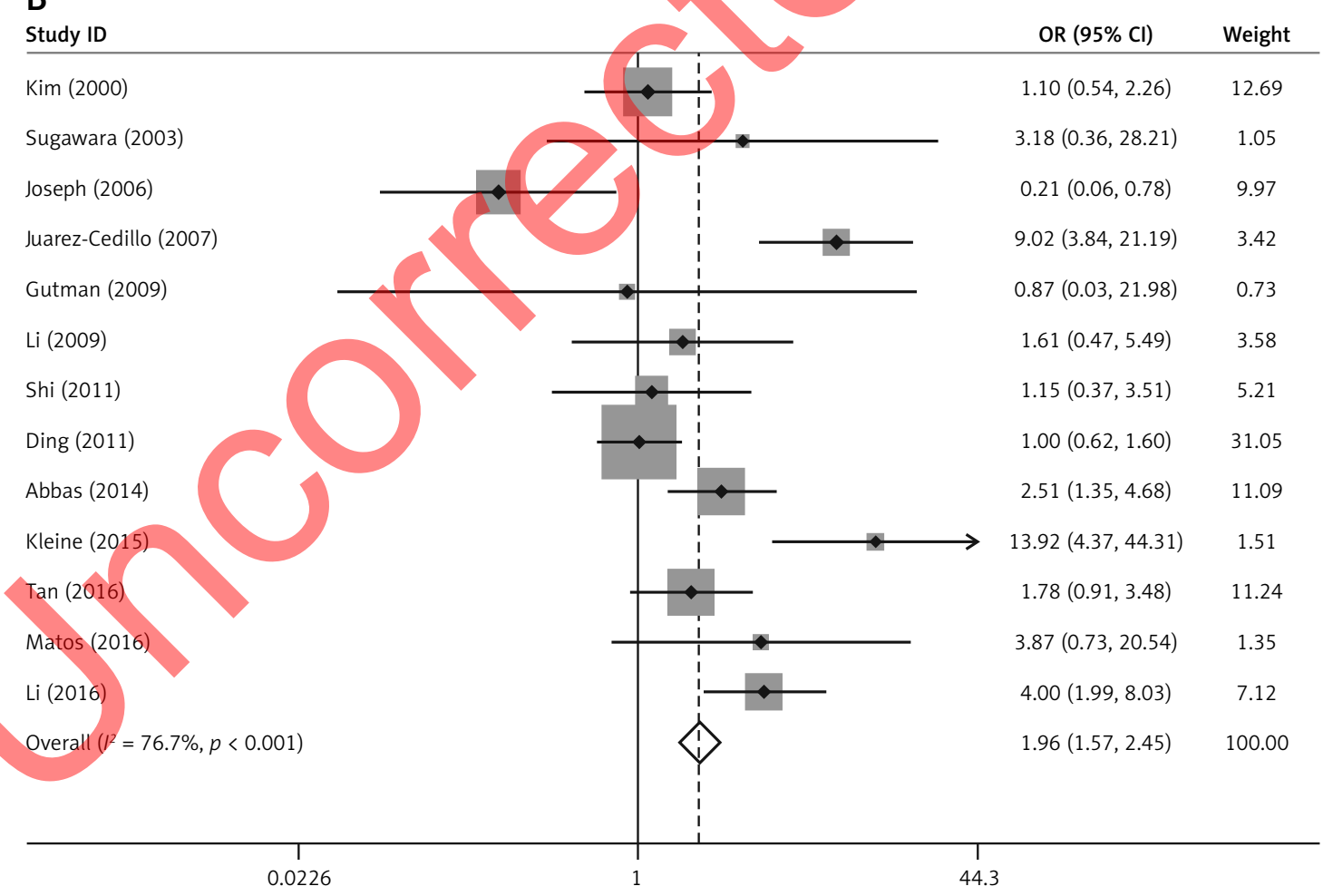

Figure 2. Significant association between CYP1A1 Mspl polymorphism and the risk of cervical cancer as determined by (A) allele model (C vs. T, $p=0.000$ ); (B) homozygote model (CC vs. TT, $p=0.000$ ) 
C

Study ID

OR $(95 \% \mathrm{Cl}) \quad$ Weight

$\operatorname{Kim}(2000)$

Sugawara (2003)

Joseph (2006)

Juarez-Cedillo (2007)

Gutman (2009)

Li (2009)

Von (2011)

Shi (2011)

Ding (2011)

Abbas (2014)

Kleine (2015)

$\operatorname{Tan}$ (2016)

Matos (2016)

Li (2016)

Overall $\left(I^{2}=79.2 \%, p<0.001\right)$

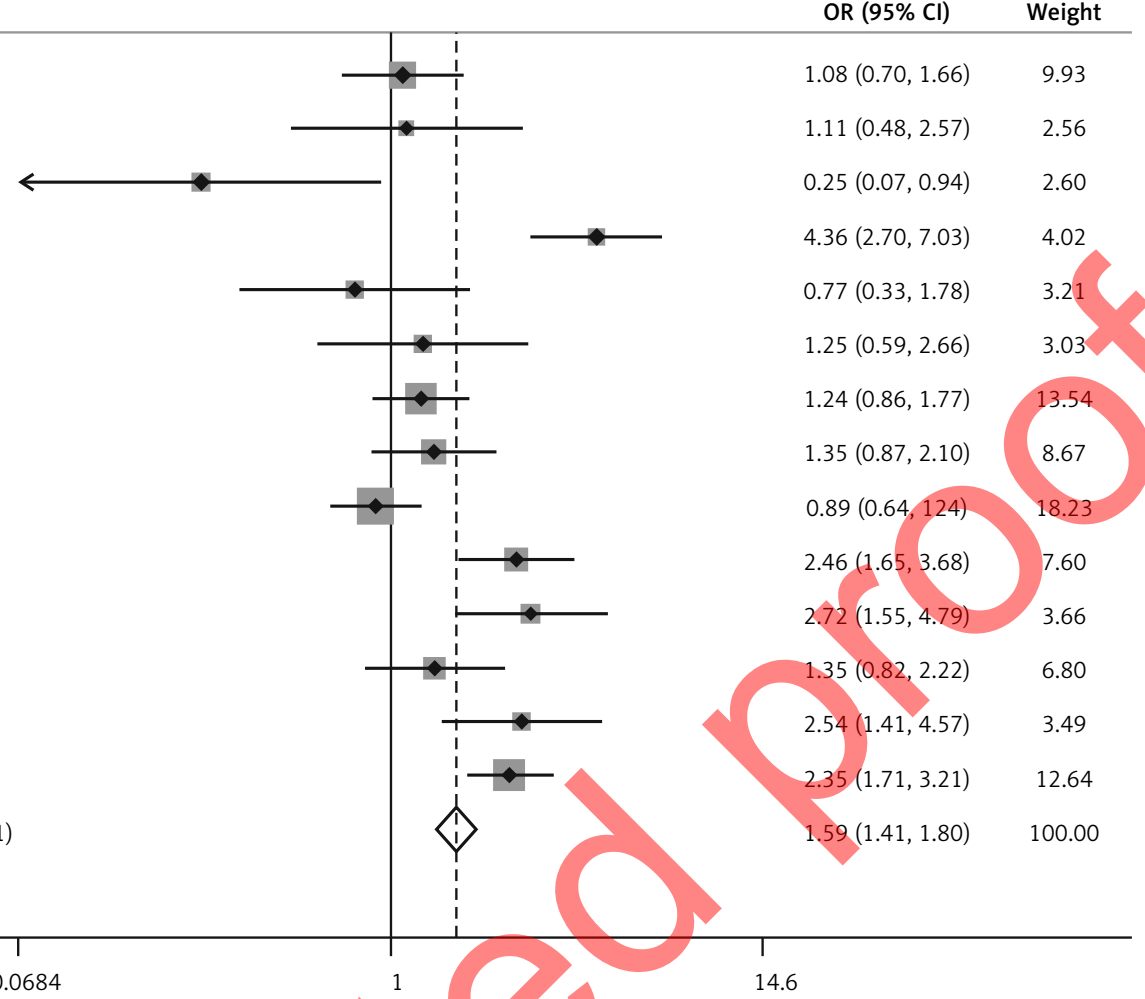

D

Study ID

14.6

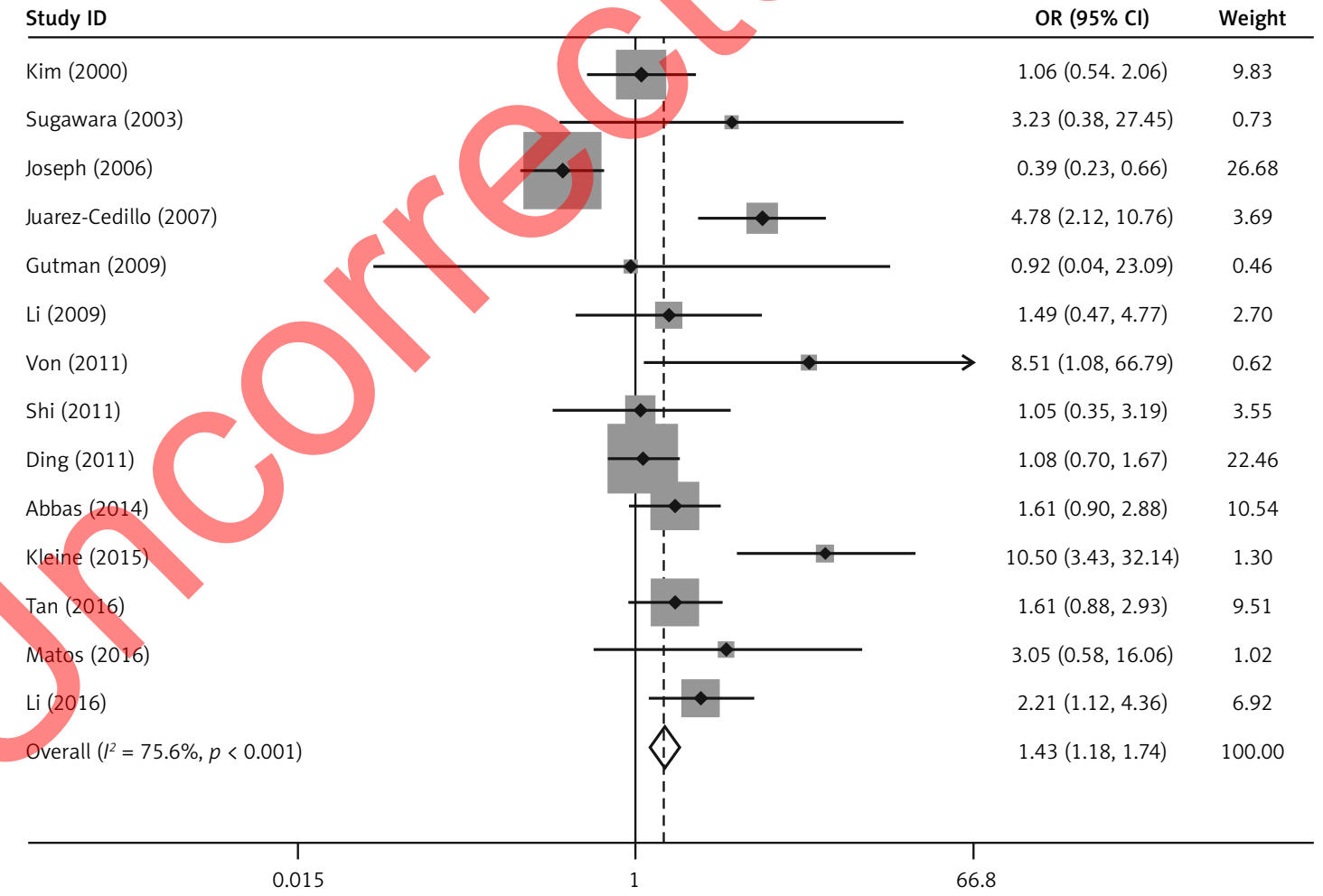

Figure 2. Cont. (C) dominant model (CC/CT vs. TT, $p=0.000$ ) and (D) recessive model (CC vs. TT/CT, $p=0.000$ ) 
In the meta-analysis stratified by ethnicity, the Mspl polymorphism was associated with cervical cancer among Caucasian women in allelic, homozygous and dominant models ( $\mathrm{C}$ vs. T, OR $=1.470$, 95\% Cl: 1.257-1.719, $p \leq 0.001$; CC vs. TT, OR = 2.241, 95\% Cl: 1.506-3.333, $p \leq 0.001 ; \mathrm{CC} / \mathrm{CT}$ vs.TT, $\mathrm{OR}=1.650,95 \% \mathrm{Cl}: 1.344-2.025, p \leq 0.001$ ). In homozygous, dominant and recessive models, the Mspl polymorphisms was associated with cervical cancer among Asian women (CC vs. TT, OR = $1.603,95 \% \mathrm{Cl}: 1.194-2.153, p=0.002$; CC/CT vs. $\mathrm{TT}, \mathrm{OR}=1.450,95 \% \mathrm{Cl}: 1.224-1.717, p \leq 0.001$; CC vs. TT/CT, OR $=1.321,95 \% \mathrm{Cl}: 1.005-1.737$, $p=0.046$ ) (Table II).

\section{Meta-analysis results for lle462Val}

There were 11 studies that analyzed the Ile462Val polymorphism, including 2137 patients and 2116 healthy controls. As shown in Figure 3, the Ile462Val polymorphism of the CYP1A1 gene was significantly associated with the risk of cervical cancer (Figure $3 \mathrm{~A}$, Val vs. Ile, $\mathrm{OR}=1.338,95 \%$ $\mathrm{Cl}: 1.199-1.493, p \leq 0.001$ ) (Figure $3 \mathrm{~B}$, ValVal vs. llelle, $\mathrm{OR}=1.576,95 \% \mathrm{Cl}: 1.188-2.090, p=0.002$ ) (Figue 3 C, ValVal/Vallle vs. Ilelle, OR $=1.498 ; 95 \%$ Cl: $1.299-1.728, p \leq 0.001)$. However, no correlation was found in the recessive model (Figure $3 \mathrm{D}$, ValVal vs. Ilelle/Vallle, OR $=1.262,95 \% \mathrm{Cl}: 0.995$ $1.600, p=0.055)$.

Subgroup analysis by ethnicity found that the Ile462Val polymorphism had an association with the risk of cervical cancer among Caucasian women in allelic and dominant models (Val vs. Ile, OR
$=1.701,95 \% \mathrm{Cl}: 1.392-2.077, p \leq 0.001$; ValVal/ Vallle vs. Ilelle, $\mathrm{OR}=1.405,95 \% \mathrm{Cl}: 1.247-1.583$, $p \leq 0.001)$. In allelic, homozygous and dominant models, the lle462Val polymorphism had associations with the risk of cervical cancer among Asian women (Val vs. Ile, OR = 1.210, 95\% Cl: 1.062$1.379, p=0.004$; ValVal vs. Ilelle, $\mathrm{OR}=1.575,95 \%$ Cl: 1.156-2.146, $p=0.004$; ValVal/Vallle vs. Ilelle, $\mathrm{OR}=1.313,95 \% \mathrm{Cl}: 1.101-1.565, p=0.002)(\mathrm{Ta}$ ble III).

\section{Publication bias analysis}

Publication bias was assessed by funnel plots and modified Egger's test, and no possible publication bias was found. The results of Egger's test of Mspl genotypes were C vs. T, $p=0.219$; CC vs. TT, $p=0.127$; CC/CT vs.TT, $p=0.331$; CC vs. TT/ $\mathrm{CT}, p=0.631$ (Figure 4). The results of Egger's test of Ile462Val genotypes were Val vs. Ile, $p=0.891$; ValVal vs. Ilelle, $p=0.233$; ValVal/Vallle vs. Ilelle, $p=0.825$; ValValvs. Ilelle/Vallle, $p=0.279$ (Figure 5). Similar results were obtained by funnel plots (Figures 6 and 7)

\section{Discussion}

Cervical cancer is still the most important gynecological malignancy in developing countries, with the incidence increasing year by year [38]. Cytochrome P450 1A1 mainly participates in the occurrence of cancer by regulating the metabolism of proteins, DNA, lipids and estrogens [39, 40]. A number of studies have reported the association between CYP1A1 gene polymorphism and

Table II. Meta-analysis of the association between CYP1A1 gene Mspl polymorphism and cervical cancer risk

\begin{tabular}{|c|c|c|c|c|c|}
\hline Contrast model & $\begin{array}{c}\text { Number of } \\
\text { studies }\end{array}$ & $\begin{array}{l}\text { Subjects } \\
\text { cases/controls) }\end{array}$ & OR $(95 \% \mathrm{Cl})$ & $P$-value & $I^{2}(\%)$ \\
\hline \multicolumn{6}{|l|}{ Total studies: } \\
\hline C vs. T & & $2448 / 2520$ & $1.333(1.214-1.464)$ & $\leq 0.001$ & 89.1 \\
\hline CC vs. TT & 14 & $2448 / 2520$ & $1.962(1.571-2.450)$ & $\leq 0.001$ & 76.7 \\
\hline & 14 & $2448 / 2520$ & $1.591(1.406-1.800)$ & $\leq 0.001$ & 79.2 \\
\hline & 14 & $2448 / 2520$ & $1.429(1.177-1.736)$ & $\leq 0.001$ & 75.6 \\
\hline \multicolumn{6}{|l|}{ Subgroup analysis: } \\
\hline \multicolumn{6}{|l|}{ Caucasians: } \\
\hline C vs. T & 7 & $999 / 1137$ & $1.470(1.257-1.719)$ & $\leq 0.001$ & 91.0 \\
\hline CC vs. TT & 7 & $999 / 1137$ & $2.241(1.506-3.333)$ & $\leq 0.001$ & 79.1 \\
\hline CC/CT vs. TT & 7 & $999 / 1137$ & $1.650(1.344-2.025)$ & $\leq 0.001$ & 74.4 \\
\hline CC vs. TT/CT & 7 & $999 / 1137$ & $1.225(0.905-1.658)$ & 0.190 & 84.2 \\
\hline \multicolumn{6}{|l|}{ Asians: } \\
\hline C vs. T & 7 & $1240 / 1163$ & $1.088(0.957-1.238)$ & 0.199 & 70.6 \\
\hline CC vs. TT & 7 & $1240 / 1163$ & $1.603(1.194-2.153)$ & 0.002 & 61.6 \\
\hline CC/CT vs. TT & 7 & $1240 / 1163$ & $1.450(1.224-1.171)$ & $\leq 0.001$ & 77.2 \\
\hline CC vs. TT/CT & 7 & $1240 / 1163$ & $1.321(1.005-1.737)$ & 0.046 & 0.0 \\
\hline
\end{tabular}


A

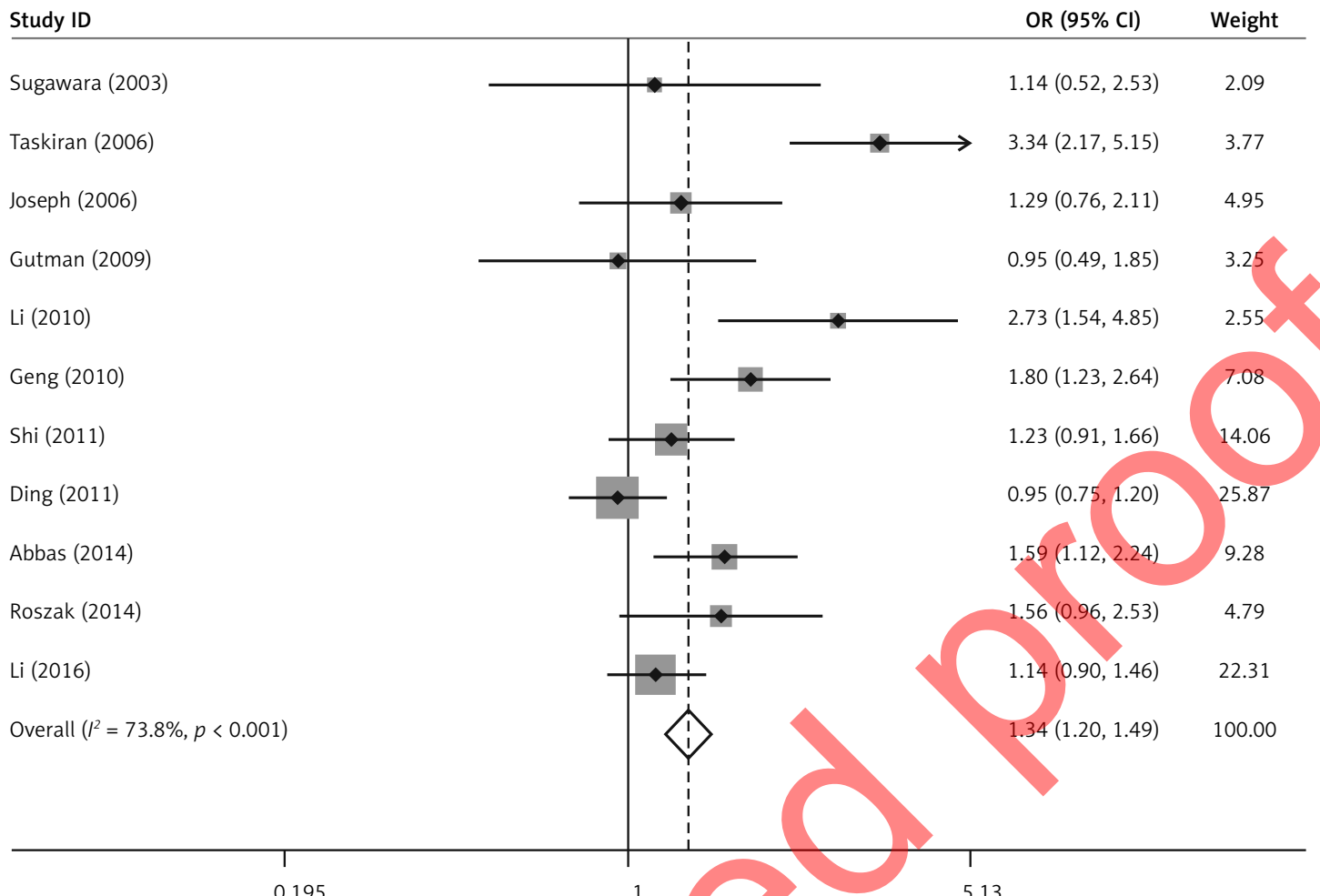

B

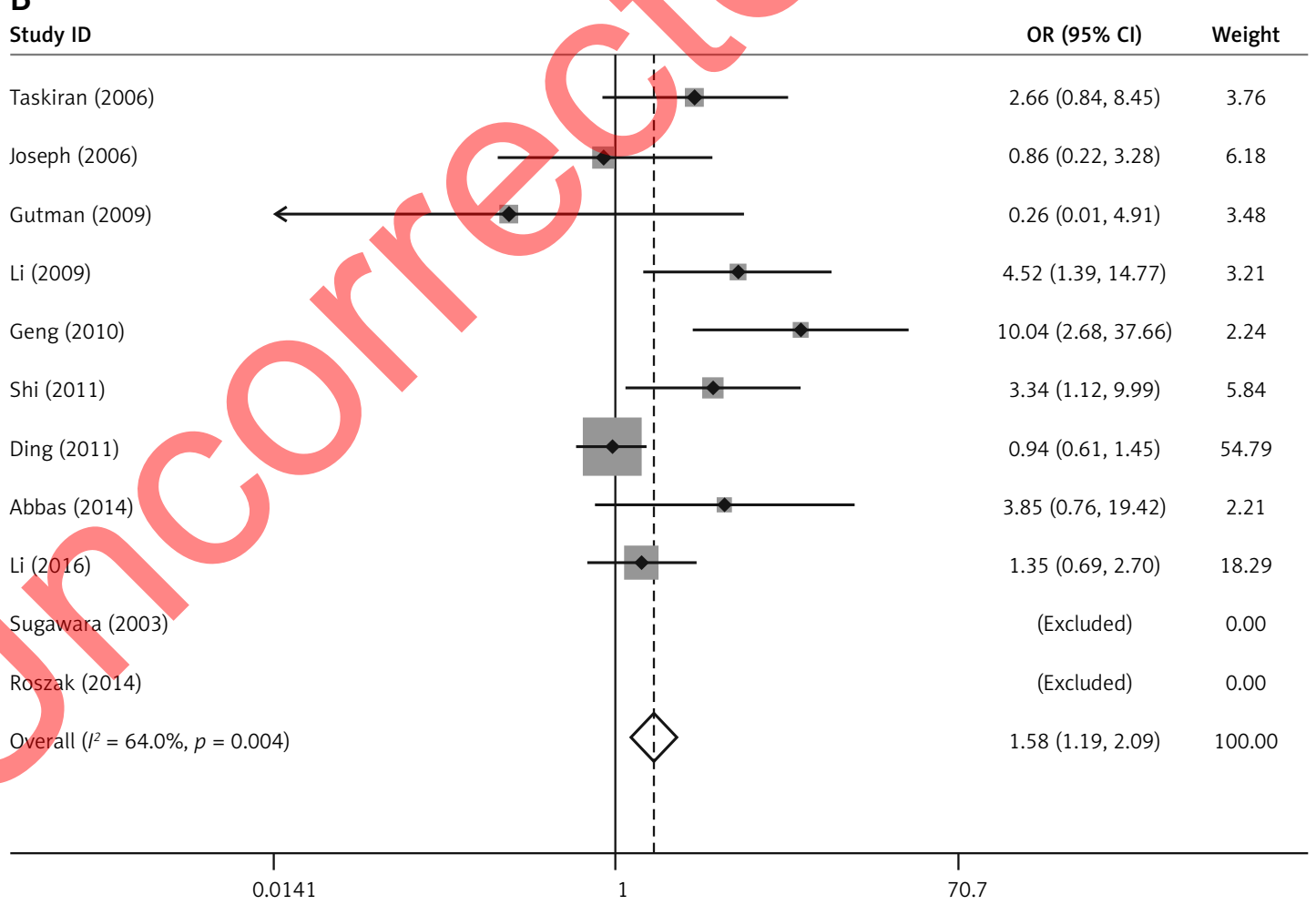

Figure 3. Significant association between CYP1A1 Ile462Val polymorphism and the risk of cervical cancer as determined by (A) allele model (Val vs. Ile, $p=0.000)$, (B) homozygote model (ValVal vs. Ilelle, $p=0.009$ ) 
C

Study ID

Sugawara (2003)

Taskiran (2006)

Joseph (2006)

Gutman (2009)

Li (2010)

Geng (2010)

Shi (2011)

Ding (2011)

Abbas (2014)

Roszak (2014)

Li (2016)

Overall $\left(I^{2}=73.4 \%, p<0.001\right)$

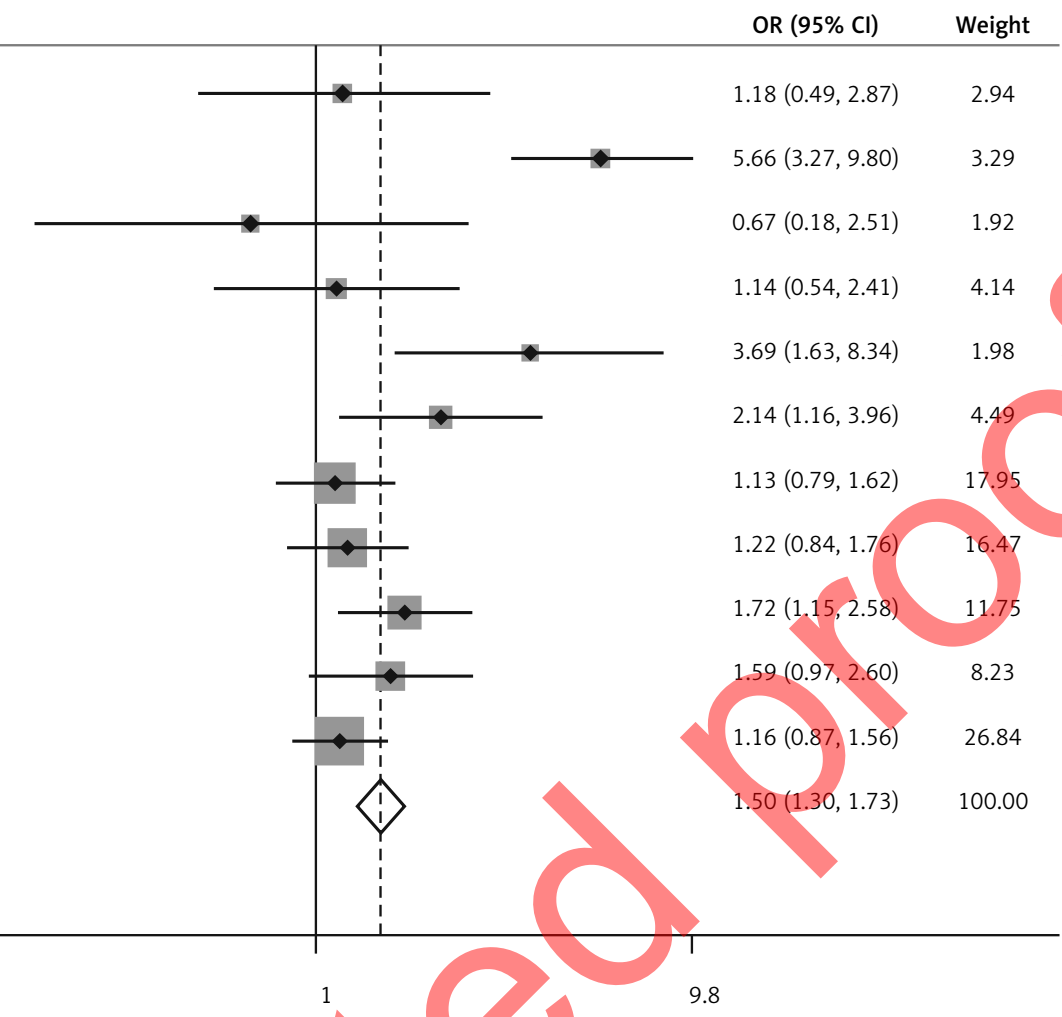

D

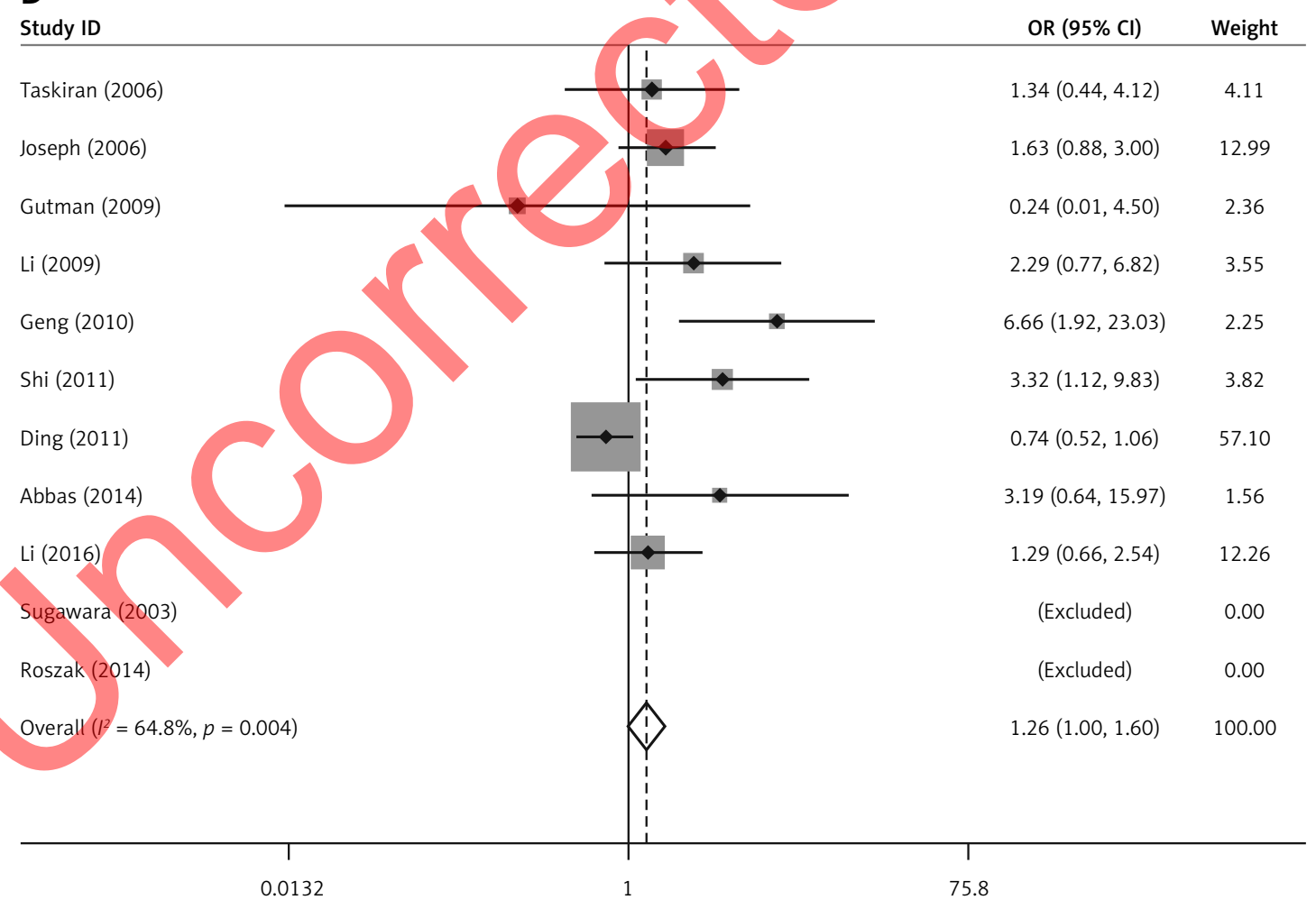

Figure 3. Cont. (C) dominant model (ValVal/Vallle vs. Ilelle, $p=0.000$ ) and (D) recessive model (ValVal vs. Ilelle/ Vallle, $p=0.055)$ 
Table III. Meta-analysis of the association between CYP1A1 gene lle462Val polymorphism and cervical cancer risk

\begin{tabular}{|c|c|c|c|c|c|}
\hline Contrast model & $\begin{array}{l}\text { Number } \\
\text { of studies }\end{array}$ & $\begin{array}{c}\text { Subjects } \\
\text { (cases/controls) }\end{array}$ & OR $(95 \% \mathrm{Cl})$ & $P$-value & $I^{2}(\%)$ \\
\hline \multicolumn{6}{|l|}{ Total studies: } \\
\hline Val vs. Ile & 11 & $2137 / 2116$ & $1.338(1.199-1.493)$ & $\leq 0.001$ & 73.8 \\
\hline ValVal vs. Ilelle & 11 & $2137 / 2116$ & $1.576(1.188-2.090)$ & 0.002 & 64.0 \\
\hline ValVal/Vallle vs. Ilelle & 11 & $2137 / 2116$ & $1.498(1.299-1.728)$ & $\leq 0.001$ & 73.4 \\
\hline ValVal vs. Ilelle/Vallle & 11 & $2137 / 2116$ & $1.262(0.995-1.600)$ & 0.055 & 64.8 \\
\hline \multicolumn{6}{|l|}{ Subgroup analysis: } \\
\hline \multicolumn{6}{|l|}{ Caucasians: } \\
\hline Val vs. Ile & 5 & $931 / 1084$ & $1.701(1.392-2.077)$ & $\leq 0.001$ & 71.2 \\
\hline ValVal vs. Ilelle & 5 & $931 / 1084$ & $1.580(0.794-3.145)$ & 0.193 & 28.2 \\
\hline ValVal/Vallle vs. Ilelle & 5 & $931 / 1084$ & $1.405(1.247-1.583)$ & $\leq 0.001$ & 96.3 \\
\hline ValVal vs. Ilelle/Vallle & 5 & $931 / 1084$ & $1.530(0.940-2.489)$ & 0.087 & 0.0 \\
\hline \multicolumn{6}{|l|}{ Asians: } \\
\hline Val vs. Ile & 6 & $1206 / 1032$ & $1.210(1.062-1.379)$ & 0.004 & 69.0 \\
\hline ValVal vs. Ilelle & 6 & $1206 / 1032$ & $1.575(1.156-2.146)$ & 0.004 & 77.8 \\
\hline ValVal/Vallle vs. Ilelle & 6 & $1206 / 1032$ & $1.313(1.101-1.565)$ & 0.002 & 58.7 \\
\hline ValVal vs. Ilelle/Vallle & 6 & $1206 / 1032$ & $1.190(0.907-1.561)$ & 0.208 & 78.9 \\
\hline
\end{tabular}

A

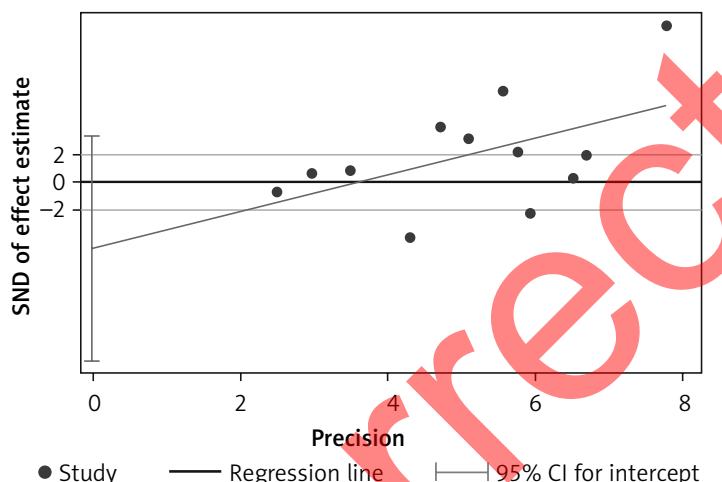

C

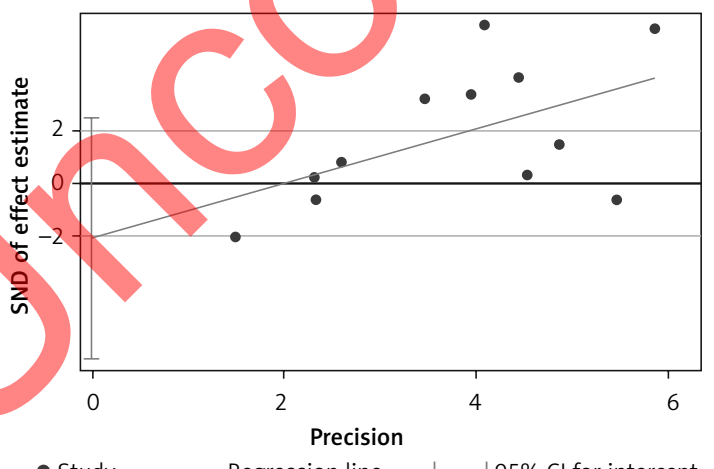

B

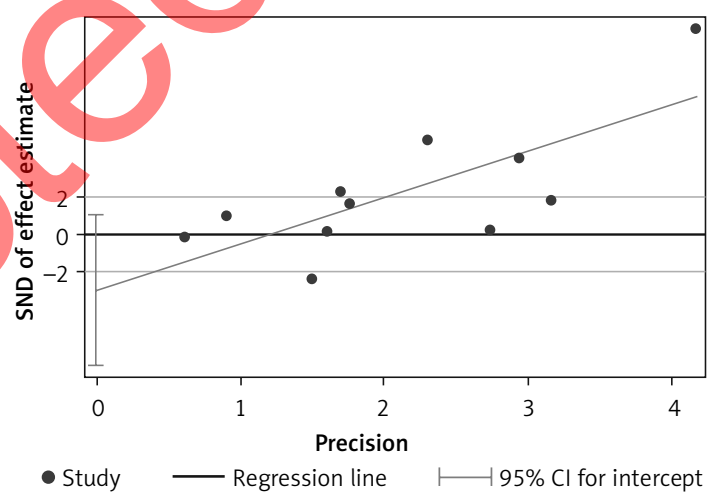

D

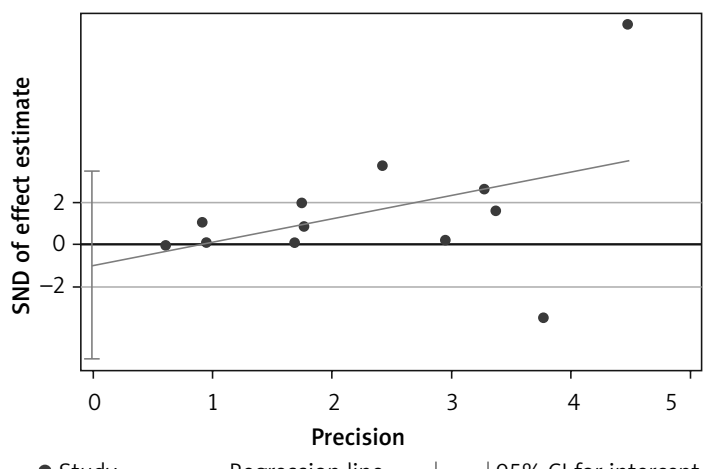

Figure 4. Egger's test on Mspl polymorphism did not show any obvious evidence of publication bias in all genetic models. A - allele model (C vs. T, $p=0.219$ ); $\mathbf{B}$ - homozygote model (CC vs. TT, $p=0.127$ ); C - dominant model (CC/ CT vs. TT, $p=0.331$ ); $\mathbf{D}$ - recessive model (CC vs. TT/CT, $p=0.631$ ) 
A

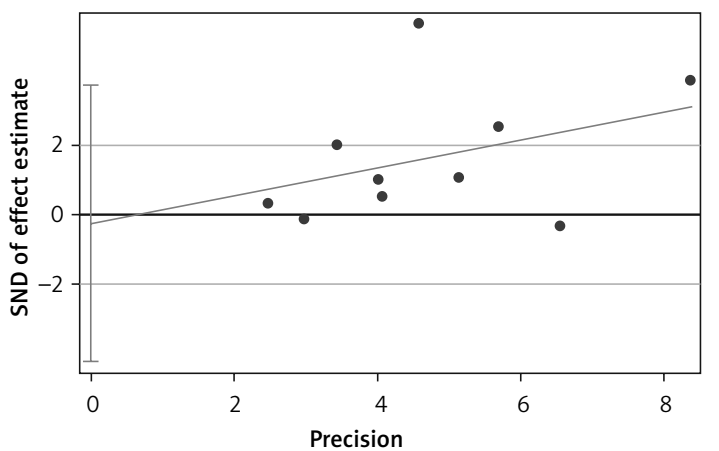

- Study $\quad$ Regression line $\quad \longmapsto 95 \%$ Cl for intercept

C

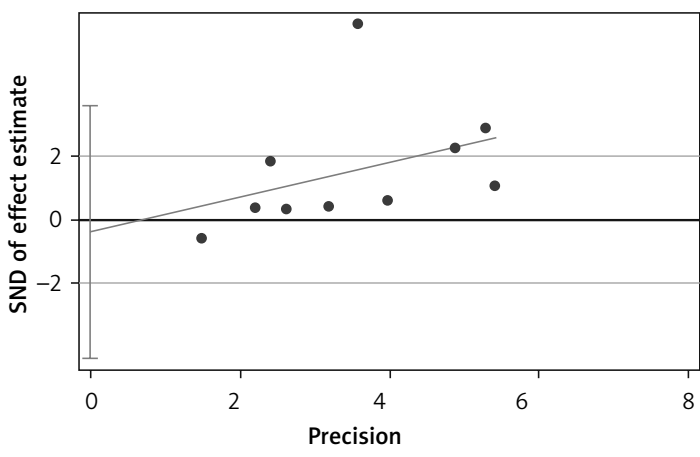

B

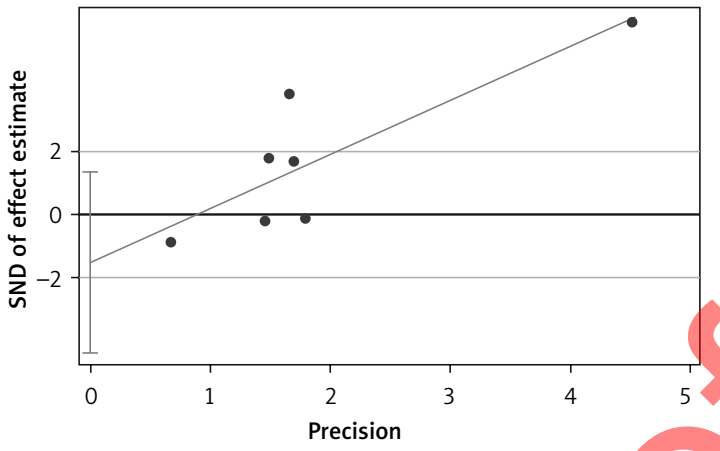

- Study $\quad$ Regression line $\longmapsto 95 \%$ Cl for intercept

D

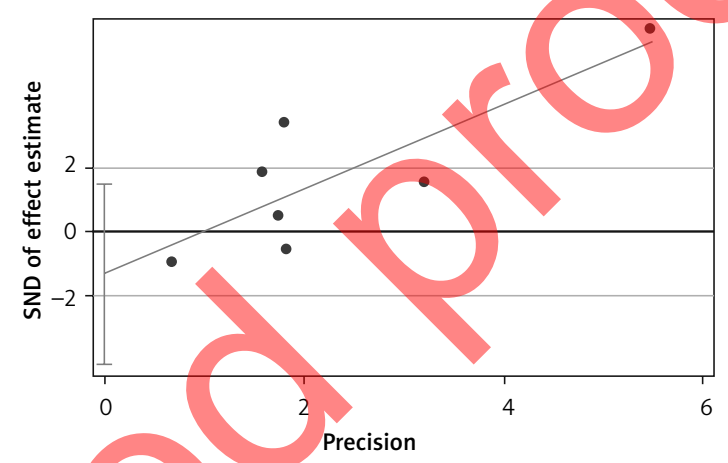

- Study $\quad$ Regression line $\quad \longmapsto-195 \% \mathrm{Cl}$ for intercept

Figure 5. Egger's test on lle462Val polymorphism did not show any obvious evidence of publication bias in all genetic models. A - allele model (Val vs. Ile, $p=0.891$ ), $\mathbf{B}$ - homozygote model (ValVal vs. Ilelle, $p=0.233$ ), C - dominant model (ValVal/Vallle vs. Ilelle, $p=0.825)$; $\mathbf{D}$ - recessive model (ValVal vs. Ilelle/Vallle, $p=0.279)$

A Funnel plot with pseudo $95 \%$ confidence limits

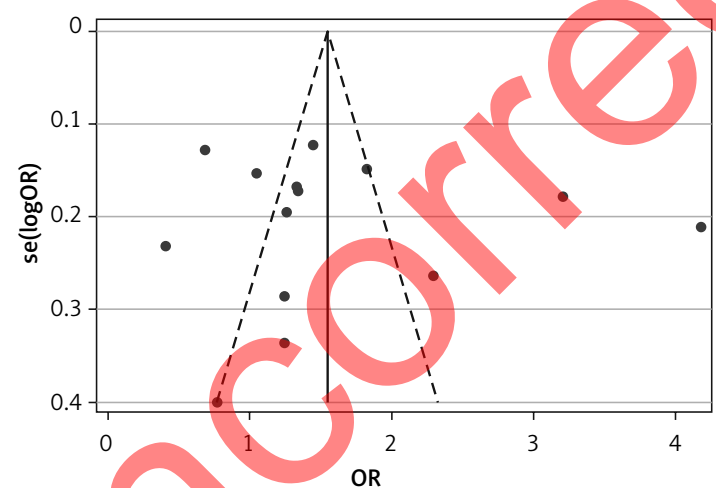

OR

C Funnel plot with pseudo $95 \%$ confidence limits

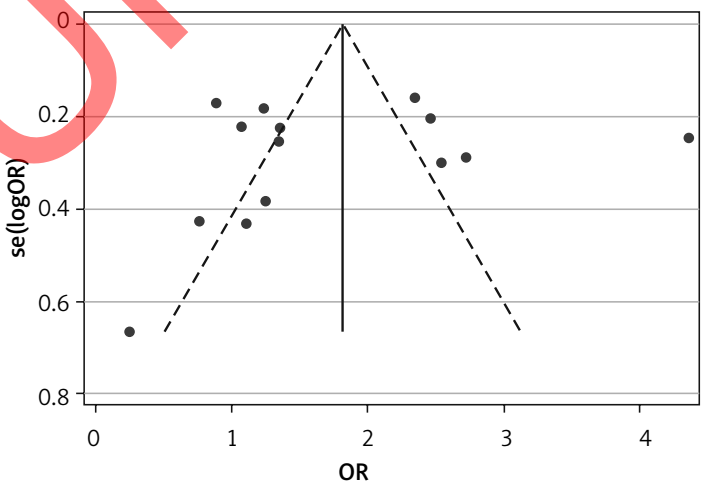

B Funnel plot with pseudo $95 \%$ confidence limits

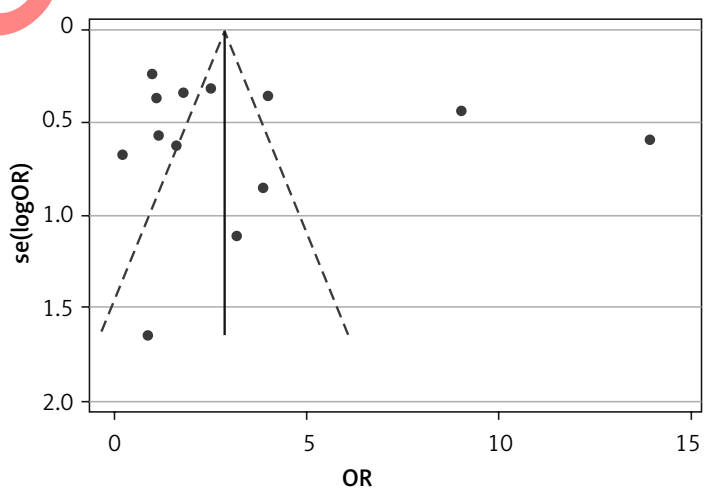

D Funnel plot with pseudo $95 \%$ confidence limits

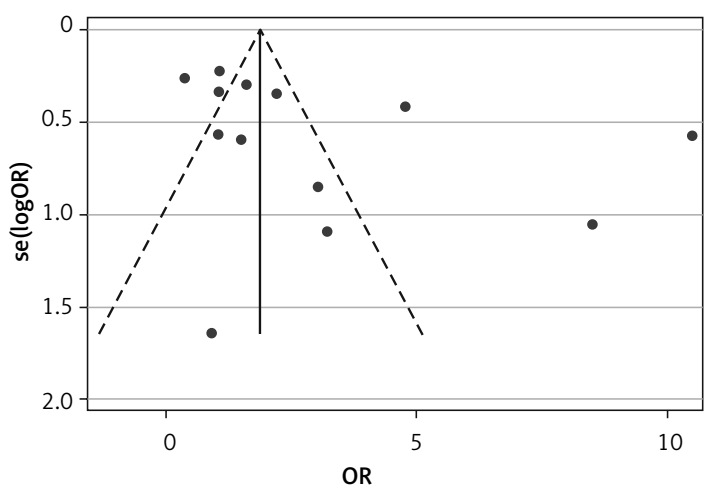

Figure 6. Funnel plots of Mspl polymorphism did not show any obvious evidence of publication bias in all genetic models. A - allele model (C vs. T); B - homozygote model (CC vs. TT); C - dominant model (CC/CT vs. TT); D - recessive model (CC vs. TT/CT) 
A

Funnel plot with pseudo $95 \%$ confidence limits

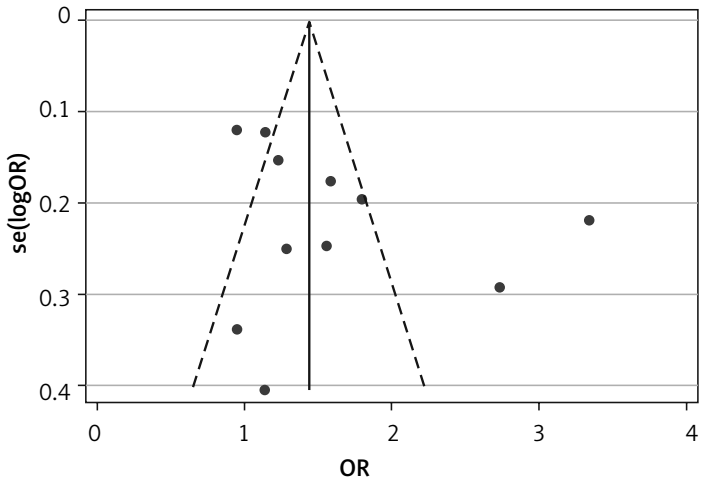

C

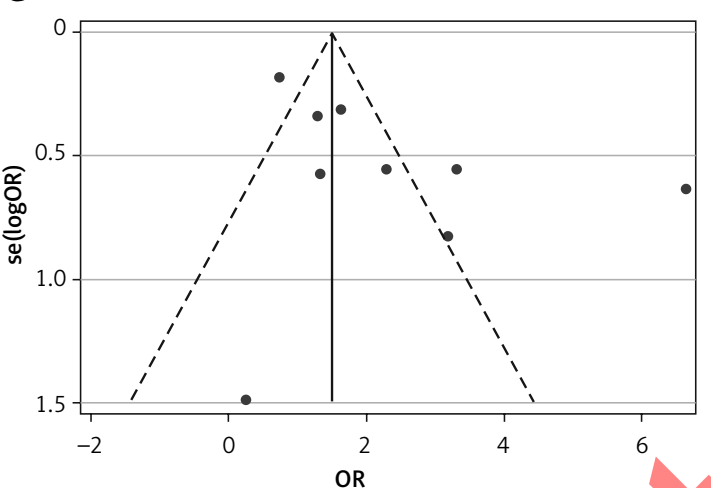

B Funnel plot with pseudo $95 \%$ confidence limits

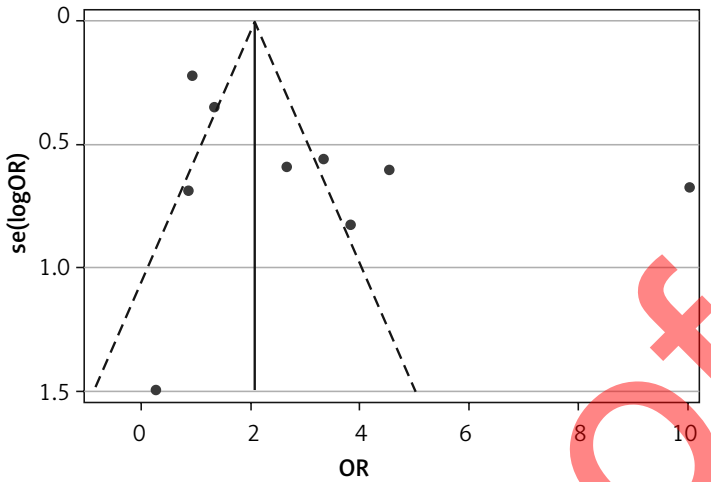

D

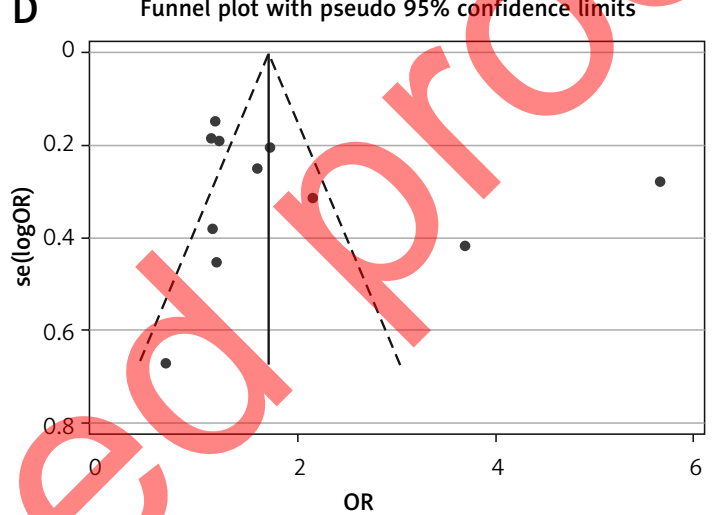

Figure 7. Funnel plots of Ile $462 \mathrm{Val}$ polymorphism did not show any obvious evidence of publication bias in all genetic models. A - allele model (Val vs. Ile); B - homozygote model (ValVal vs. Ilelle); C - dominant model (ValVal/ Vallle vs. Ilelle); D - recessive model (ValVal vs. Ilelle/Vallle)

the susceptibility to cervical cancer, but the conclusion is controversial due to the differences in the study design, the study population, the detection method and the sample size [19-22]. Therefore, the current study investigated the correlation between CYP1A1 gene polymorphism and cervical cancer susceptibility through a meta-analysis on 17 studies.

A total of 14 articles on the Mspl polymorphism were enrolled in our study, which included 2448 patients and 2520 healthy controls. Analysis results of allelic, homozygous, dominant and recessive models all indicate that the Mspl polymorphism of the CYP1A1 gene is closely associated with the risk of cervical cancer. This result is in accordance with a meta-analysis on the relationship between Mspl polymorphism and cervical cancer by Xia et al. [41]. Additionally, analysis stratified by ethnicity showed the association of Mspl polymorphism and the risk of cervical cancer in Caucasian women and Asian women in multiple genetic variants. However, a study by Sergentanis et al. failed to identify any association between Mspl polymorphism and cervical cancer susceptibility among Asian women, in which only 3 articles on an Asian population were included [42]. We suppose that the results of our study are more accurate because the small number of studies on Asian women in their study may increase the inaccuracy of the meta-analysis conclusions.

For meta-analysis of Ile462Val polymorphism, 11 articles including 2137 cervical cancer patients and 2116 healthy controls were enrolled. We found that the lle462Val polymorphism of the CYP1A1 gene was significantly associated with the risk of cervical cancer. Subgroup analysis by ethnicity showed that the Ile462Val polymorphism was associated with the risk of cervical cancer among Caucasian women in allelic and dominant models, and among Asian women in allelic, homozygous and dominant models. Generally our results are similar to those of Yang et al. and Sergentanis et al. [42, 43]. However, their studies did not report the association between Ile462Val polymorphism and cervical cancer susceptibility in the Asian population. We speculate that the difference in results may due to differences in the number of selected articles as well as the number of cases $[42,43]$. Further meta-analysis with larger samples is still needed to obtain a more accurate conclusion for the association between lle462Val polymorphism and cervical cancer susceptibility in Asian women.

Previous studies have reported differences in the association between CYP1A1 gene Mspl polymorphism and susceptibility to different cancers $[42,44,45]$. In addition, the lle462Val polymor- 
phism is closely related to the risk of ovarian cancer, lung cancer and liver cancer, but is not related to the risk of gastric cancer or breast cancer [4448]. Here, in the current meta-analysis, we found that both $\mathrm{Mspl}$ and Ile462Val polymorphisms were associated with the risk of cervical cancer, indicating that these polymorphisms may have distinctive roles in different kinds of cancer. This may be caused by the specific CYP1A1 functions in different tissues or cells.

The present study had some limitations. First, data on the family history, smoking, drinking, age and other environmental exposure factors were lacking for the enrolled articles. Thus, non-adjusted ORs were obtained. Second, due to the lack of adequate pathological data, stratified analysis could not be done based on pathological types. Third, there was heterogeneity among the included studies. Fourth, this study did not analyze the interactions between genes or between genes and the environment and their impact on the association between gene polymorphisms and cancer.

In summary, this meta-analysis demonstrates that the Mspl and Ile462 Val polymorphisms of the CYP1A1 gene are involved in the development of cervical cancer. To further verify such associations, studies with a larger number of samples, accurate sample information and reasonable study designs are warranted.

\section{Acknowledgments}

This study was supported by the Natural Sci ence Foundation of Xinjiang Uygur Autonomous Region (grant number 2015211C059).

\section{Conflict of interest}

The authors declare no conflict of interest.

\section{Reference}

1. Remmink AJ, Walboomers JM, Helmerhorst TJ et al. The presence of persistent high-risk HPV genotypes in dysplastic cervical lesions is associated with progressive disease: natural history up to 36 months. Int J Cancer 1995; 61: 306-11.

2. Schiffman M, Castle PE, Jeronimo J, Rodriguez AC, Wacholder S. Human papillomavirus and cervical cancer. Lancet 2007: 370: 890-907.

3. Goldie SJ, Gaffikin L, Goldhaber-Fiebert JD, et al. Cost effectiveness of cervical screening in five developing countries. N Eng J Med 2005; 353: 2158-68

4. Barbisan G, Contreras A, Perez LO, Difranza L, Golijow CD. The effect of TP53 codon 72 and RNASEL codon 462 polymorphisms on the development of cervical cancer in Argentine women. Cancer Genet 2011; 204: 270-7.

5. Burd EM. Human papillomavirus and cervical cancer. Clin Microbiol Rev 2003; 16: 1-17.

6. Turkler C, Kiremitli T. A retrospective analysis of women diagnosed with unclassified HPV genotypes. Arch Med Sci Civil Dis 2019; 4: e22-7.
7. Chatterjee S, Chattopadhyay A, Samanta L, Panigrahi P. HPV and cervical cancer epidemiology - current status of HPV vaccination in India. Asian Pac J Cancer Prev 2016; 17: 3663-73.

8. Vasilevska M, Ross SA, Gesink D, Fisman DN. Relative risk of cervical cancer in indigenous women in Australia, Canada, New Zealand, and the United States: a systematic review and meta-analysis. J Public Health Policy 2012; 33: 148-64.

9. Saslow D, Solomon D, Lawson HW, et al. American Cancer Society, American Society for Colposcopy and Cervical Pathology, and American Society for Clinical Pathology screening guidelines for the prevention and early detection of cervical cancer. J Low Genit Tract Dis 2012; 16: 175-204.

10. Bartsch H, Rojas M, Nair U, Nair J, Alexandrov K Genetic cancer susceptibility and DNA adducts: studies in smokers, tobacco chewers, and coke oven workers. Cancer Detect Prev 1999; 23: 445-53.

11. Bolton JL, Thatcher GR. Potential mechanisms of estrogen quinone carcinogenesis. Chem Res Toxicol 2008; 21: 93-101.

12. Yager JD. Endogenous estrogens as carcinogens through metabolic activation. J Natl Cancer Inst Monogr 2000; 27: 67-73.

13. Martinez-Ramirez OC, Perez-Morales R, Castro C, et al. Polymorphisms of catechol estrogens metabolism pathway genes and breast cancer risk in Mexican women. Breast 2013; 22: 335-43.

14. Tsuchiya Y, Nakajima M, Yokoi T. Cytochrome P450-mediated metabolism of estrogens and its regulation in human. Cancer Lett 2005; 227: 115-24.

15. Crow JM. HPV: The global burden. Nature 2012; 488 52-3.

16. Moody CA, Laimins LA. Human papillomavirus oncoproteins: pathways to transformation. Nat Rev Cancer 2010; 10: 550-60.

17. Chung SH, Franceschi S, Lambert PF. Estrogen and ERalpha: culprits in cervical cancer? Trends Endocrinol Metab 2010; 21: 504-11.

18. Hao JQ, Zhang QK, Zhou YX, Chen LH, Wu PF. Association between circulating leptin concentration and G-2548A gene polymorphism in patients with breast cancer: a meta-analysis. Arch Med Sci 2019; 15: 275-83.

19. Matos A, Castelao C, Pereira da Silva A, et al. Epistatic Interaction of CYP1A1 and COMT Polymorphisms in Cervical Cancer. Oxid Med Cell Longev 2016; 2016: 2769804.

20. Li S, Li G, Kong F, et al. The association of CYP1A1 gene with cervical cancer and additional SNP-SNP interaction in Chinese women. J Clin Lab Anal 2016; 30: 1220-5.

21. Tan YH, Sidik SM, Syed Husain SN, Lye MS, Chong PP. CYP1A1 Mspl polymorphism and cervical carcinoma risk in the multi-ethnic population of malaysia: a case-control study. Asian Pac J Cancer Prev 2016; 17: 57-64.

22. Kleine JP, Camargo-Kosugi CM, Carvalho CV, Silva FC, Silva ID. Analysis of CYP1A1 and COMT polymorphisms in women with cervical cancer. Genet Mol Res 2015; 14: 18965-73.

23. Spurr NK, Gough AC, Stevenson K, Wolf CR. Msp-1 polymorphism detected with a CDNA probe for the P-450 I family on chromosome 15. Nucleic Acids Res 1987; 15: 5901.

24. Petersen DD, McKinney CE, Ikeya K, et al. Human CYP1A1 gene: cosegregation of the enzyme inducibility phenotype and an RFLP. Am J Hum Genet 1991; 48: 720-5. 
25. Abbas M, Srivastava K, Imran M, Banerjee M. Association of CYP1A1 gene variants rs4646903 ( $T>C)$ and rs1048943 (A>G) with cervical cancer in a North Indian population. Eur J Obstet Gynecol Reprod Biol 2014; 176: 68-74.

26. Ding F, Guifang MA, Song X. Relationship between CYP1A1 gene polymorphism and genetic susceptibility of cervical carcinoma. Jiangsu Med J 2011; 37: 2562-4.

27. Gutman G, Morad T, Peleg B, et al. CYP1A1 and CYP2D6 gene polymorphisms in Israeli Jewish women with cervical cancer. Int J Gynecol Cancer 2009; 19: 1300-2.

28. Joseph T, Chacko P, Wesley R, Jayaprakash PG, James FV, Pillai MR. Germline genetic polymorphisms of CYP1A1, GSTM1 and GSTT1 genes in Indian cervical cancer: associations with tumor progression, age and human papillomavirus infection. Gynecol Oncol 2006; 101: 411-7.

29. Juarez-Cedillo T, Vallejo M, Fragoso JM, et al. The risk of developing cervical cancer in Mexican women is associated to CYP1A1 Mspl polymorphism. Eur J Cancer 2007; 43: 1590-5.

30. Kim JW, Lee CG, Park YG, et al. Combined analysis of germline polymorphisms of p53, GSTM1, GSTT1, CYP1A1, and CYP2E1: relation to the incidence rate of cervical carcinoma. Cancer 2000; 88: 2082-91.

31. Li A, Kong A. The relationship between polymorphisms of CYP1A1 gene and cervical squamous carcinoma. In: Progress in Obstetrics \& Gynecology. Churchill Living stone 2009

32. Shi YR, Jian G, Cheng LQ, Hui W, Yao Z. Association of cytochrome P450 1A1 gene polymorphisms with cervical cancer. Fudan Univ J Medical Sci 2011; 38: 428-31.

33. Sugawara T, Nomura E, Sagawa T, Sakuragi N, Fujimoto S CYP1A1 polymorphism and risk of gynecological malig nancy in Japan. Int J Gynecol Cancer 2003; 13: 785-90.

34. von Keyserling $H$, Bergmann $T$, Schuetz $M$, et al. Analysis of 4 single-nucleotide polymorphisms in relation to cervical dysplasia and cancer development using a high-throughput ligation-detection reaction procedure. Int J Gynecol Cancer 2011; 21: 1664-71.

35. Geng J, Shi YR, Wang H, Qin R. Research of cytochrome P450 1A1 lle/Val polymorphism and genetic susceptibility in cervical cancer. J Bengbu Med Coll 2010; 35: 762-3.

36. Roszak A, Lianeri M, Sowinska A, Jagodzinski PP. CYP1A1 lle462Val polymorphism as a risk factor in cervical cancer development in the Polish population. Mol Diagn Ther 2014; 18: 445-50.

37. Taskiran C, Aktas D, Yigit-Celik N, et al. CYP1A1 gene polymorphism as a risk factor for cervical intraepithelia neoplasia and invasive cervical cancer. Gynecol Oncol 2006; 101: 503-6.

38. Siegel RL, Miller KD, Jemal A. Cancer statistics, 2016. CA Cancer J Clin 2016; 66: 7-30.

39. Androutsopoulos VP, Tsatsakis AM, Spandidos DA. Cytochrome P450 CYP1A1: wider roles in cancer progression and prevention. BMC Cancer 2009; 9: 187.

40. Nebert DW, Dalton TP. The role of cytochrome P450 enzymes in endogenous signalling pathways and environmental carcinogenesis. Nat Rev Cancer 2006; 6: 947-60.

41. Xia L, Gao J, Liu Y, Wu K. Significant association between CYP1A1 T3801C polymorphism and cervical neoplasia risk: a systematic review and meta-analysis. Tumour Biol 2013; 34: 223-230.

42. Sergentanis TN, Economopoulos KP, Choussein S, Vlahos NF. Cytochrome P450 1A1 (CYP1A1) gene polymorphisms and cervical cancer risk: a meta-analysis. Mol Biol Rep 2012; 39: 6647-54.
43. Yang S, Jia C, Zhu H, Han S. CYP1A1 Ile462Val polymorphism and cervical cancer: evidence from a meta-analysis. Tumour Biol 2012; 33: 2265-72.

44. Masson LF, Sharp L, Cotton SC, Little J. Cytochrome P450 1A1 gene polymorphisms and risk of breast cancer: a HuGE review. Am J Epidemiol 2005; 161: 901-15.

45. Guo R, Guo X. Quantitative assessment of the associations between CYP1A1 polymorphisms and gastric cancer risk. Tumour Biol 2012; 33: 1125-32.

46. Ji YN, Wang Q, Suo LJ. CYP1A1 lle462Val polymorphism contributes to lung cancer susceptibility among lung squamous carcinoma and smokers: a meta-analysis. PLoS One 2012; 7: e43397.

47. Sergentanis TN, Economopoulos KP, Choussein S, Vlaho NF. Cytochrome P450 1A1 gene polymorphisms and endometrial cancer risk: a meta-analysis. Int I Gynecol Cancer 2011; 21: 323-31.

48. Yu L, Sun L, Jiang YF, Lu BL, Sun DR, Zhu LY. Interactions between CYP1A1 polymorphisms and cigarette smoking are associated with the risk of hepatocellular carcinoma: evidence from epidemiological studies. Mol Biol Rep 2012; 39: 6641-6.

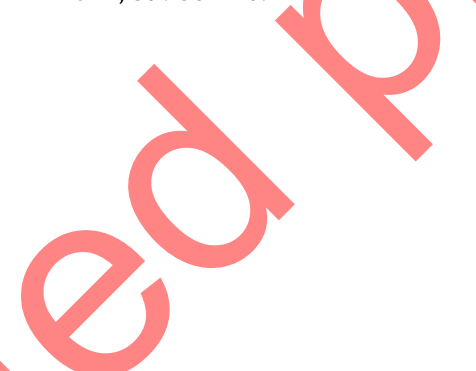

